\title{
Production of Pequi Powder by Drying Pulp
}

\author{
Aluizio Paulo Rodrigues Silva, Welisson Martins Rocha, David Maikel Fernandes, \\ José Roberto Delalibera Finzer
}

Faculty of Chemical Engineering-UNIUBE, Uberaba, MG, Brazil

Email: welissonmartins@msn.com

How to cite this paper: Silva, A.P.R., Rocha, W.M., Fernandes, D.M. and Finzer, J.R.D. (2018) Production of Pequi Powder by Drying Pulp. Agricultural Sciences, 9, 1047-1057.

https://doi.org/10.4236/as.2018.98072

Received: June 1, 2018

Accepted: August 27, 2018

Published: August 30, 2018

Copyright $\odot 2018$ by authors and Scientific Research Publishing Inc. This work is licensed under the Creative Commons Attribution International License (CC BY 4.0).

http://creativecommons.org/licenses/by/4.0/

\begin{abstract}
The pequi tree is a native plant of the Brazilian cerrado, and the scientific name is Caryocar brasiliense, whose fruits are called pequi, appreciated for its pleasant peculiarities of color, aroma and flavor. The objective of this work is to transform pequi pulp into powder, aiming at maintaining the flavor. By using the convection drying technique, the product is converted from the fluid state to the solid state in the form of a powder. Experiments were performed with drying at the following temperatures: $40^{\circ} \mathrm{C}, 50^{\circ} \mathrm{C}, 60^{\circ} \mathrm{C}, 90^{\circ} \mathrm{C}$ and $105^{\circ} \mathrm{C}$. Interpretations were made of the experimental drying and milling results. It was verified that for all the experimental temperatures, there was no loss of the sensory characteristics of pequi. The drying of the pequi pulp in a greenhouse at $105^{\circ} \mathrm{C}$ consisted of a good result of preservation of the characteristics of the fruit: color, aroma and flavor. Using the Trojan Powder Coating scale, it is found that pequi powder, dried at $105^{\circ} \mathrm{C}$, differs little in terms of the color of the fruit in nature.
\end{abstract}

\section{Keywords}

Pequi, Drying, Brazilian Cerrado

\section{Introduction}

The cerrado is located almost entirely in the Central Plateau of Brazil and constitutes the second largest national biome as a sequence of its extension, occurs a great variability of climate and soils, in addition to a great diversity of fauna and flora. Thus, the cerrado flora has several fruit species with great potential for agricultural and technological use [1].

Among the existing species, it is worth mentioning the pequi tree whose scientific name is Caryocar brasiliense, is a medium-sized tree, whose fruits are called pequi. With the estimated life cycle of approximately 50 years, it reaches up to 10 meters in 
height [2]. Its reproductive phase begins from the eighth year, with flowering and fruiting normally occurring between the months of September and November.

The fruit is constituted by an exocarp of greenish-brown coloration, an external mesocarp formed by a white pulp, which houses from 1 to 6 lumps (pyrénians), and internal mesocarp (fruit pulp) of coloration varying from pale yellow to intense orange, possessing characteristic strong odor. The spiky endocarp of the pequi protects an almond, which is also an edible portion of the fruit and is covered by a thin brownish skin [3].

Pequi is rich in oils, proteins, fibers, minerals (zinc, copper and phosphorus) and carotenoids; the fruit is also considered a potential source of vitamin A essential for the assurance of basic functions of the body, such as bone development and epithelial tissue vision, as well as benefits to immunological and reproductive processes [4].

The pequi has a shelf life in natura form and must be consumed quickly or kept under freezing during its off season. The use of the conservation technique, such as convective drying with air flow, transforms the product in the pasty state to the solid state in the form of powder with which it is used to use and preserve the pulp of the fruit, besides increasing the useful life of the product and promote the manufacture of differentiated foods [2]. The industrial use of this technology has spread since the 20th century, mainly in the alimentary, pharmaceutical and chemical area for the product of powdered milk, eggs, juices, instant coffee, medicines and soap [4].

The use of natural substances in the development of new products makes them attractive to the consumer. Therefore, the elaboration of seasonings or condiments that are mixtures of vegetable spices, besides being used to add flavor or aroma to foods also have the purpose of conservation, due to its antimicrobial, antioxidant and medicinal properties [5].

The objective of this work is to convert pequi pulp into powder to extend shelf life and ease of use in food formulations.

\section{Material and Methods}

The Project was developed as follows:

1) Obtaining of the product: to acquire fruits of pequi in the market. Sanitize the fruits by placing them immersed in water at a temperature of $70^{\circ} \mathrm{C}$ for one minute, then drain them, and immerse them in a solution of sodium hypochlorite. Proper handling and preparation of fruits and vegetables for human consumption are crucial to reducing microbial burden and may reduce the incidence of foodborne illness. The application of sodium hypochlorite is carried out for sanitization, whereby the bacteria and other microorganisms present in the pequi fruit are reduced to an acceptable number [6] [7]. Follow the washing with water at room temperature to eliminate impurities.

2) Removal of the pequi pulp, previously frozen, was done with the aid of a stainless steel grater, being careful not to reach the pequi spines (inner part of 
the fruit), thus obtaining pequi pulp in the form of chips, small pieces of the even as possible. Thus, the stage of chips drying occurs uniformly.

3) The pequi fruits were subjected to friction on the cutting surface of the stainless steel grater, obtaining the slices of the pulp (see Figure 1). After the removal of pequi pulp, the product was thawed to a temperature of $10^{\circ} \mathrm{C}$, then arranged in trays and led to a convective dryer with air flow.

It must dry the product until it reaches the necessary moisture for conservation, trying to avoid variation in the color, aroma and flavor of the fruit. Drying curves (see Figure 1) were obtained by quantifying the sample mass every 10 minutes in the first hour and every 30 minutes thereafter.

Drying is the removal of a volatile liquid, usually water, from a porous solid. Drying is generally the final step of a series of operations and the product discharged from the dryer is packaged [8] [9].

In particles drying, air is used to transfer heat to the wet material in order to evaporate the moisture, removing it from the surface of the material in the form of water vapor [10]. Air has the temperature decreased during drying while the temperature of the solids generally increases. Figure 2 is a drying curve and Figure 3 shows the Dryer that will be used in this research.

The drying time can be calculated by the Equation (1):

$$
t=\frac{W}{A}\left[\frac{X_{1}-X_{2}}{N_{C}}\right]
$$

where $W$ is the mass of dry solids; $A$ is the drying area; $X_{1}$ and $X_{2}$ are the initial and final moisture (dry basis); $N_{C}$ is the drying rate in the constant period.

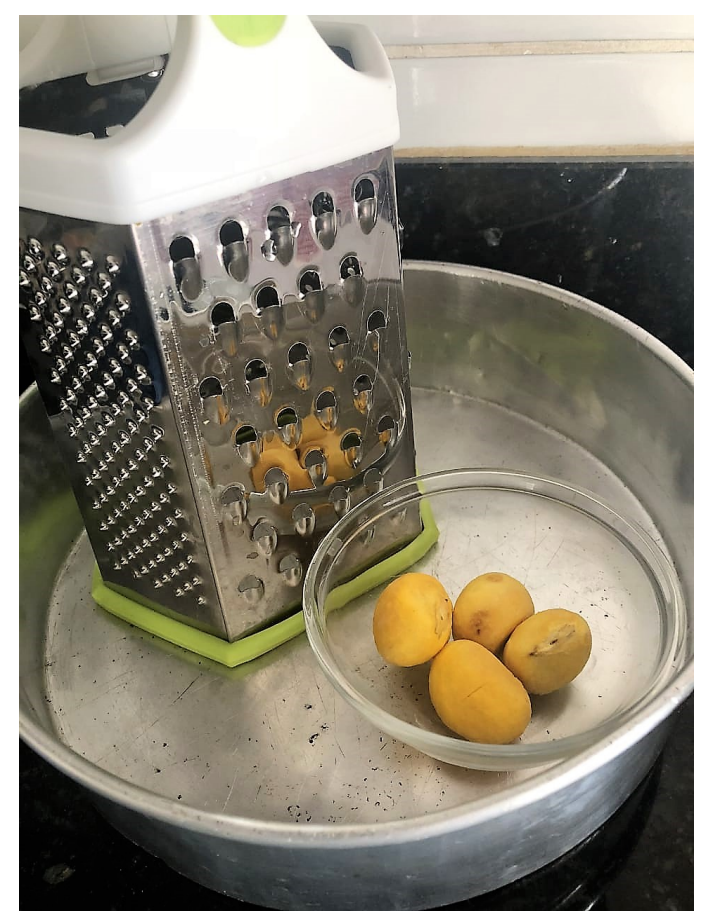

Figure 1. Pulp separating system from pequi fruits. 


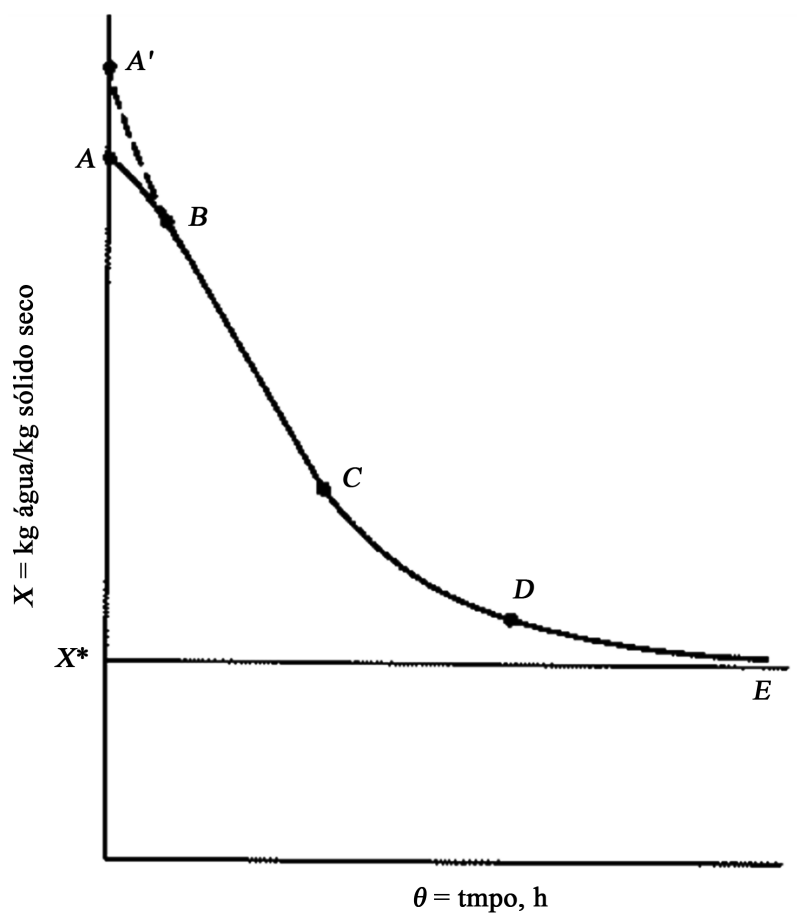

Figure 2. Drying curve.

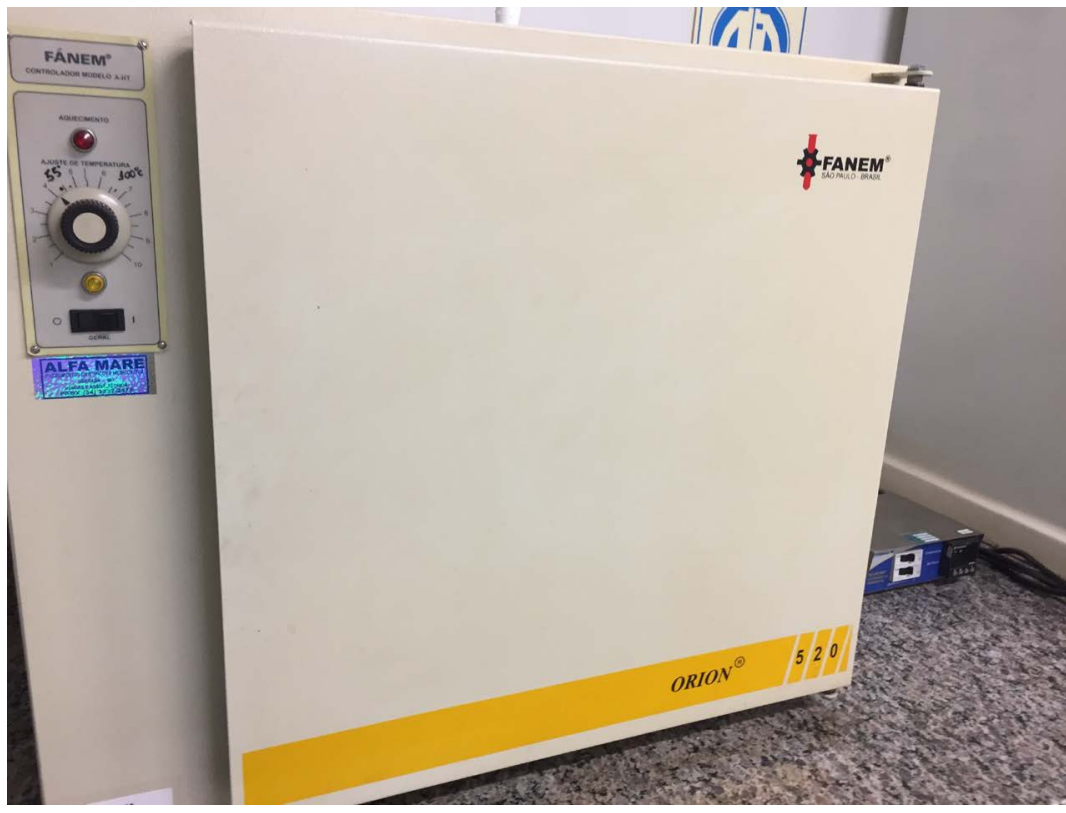

Figure 3. Fanem Orion 520 greenhouse, temperatures from $50^{\circ} \mathrm{C}$ to $250^{\circ} \mathrm{C}, 62 \mathrm{~L}$ volumetric capacity.

4) After drying the product should cool to room temperature for 10 to $15 \mathrm{mi}$ nutes so that the quality of the product is not affected and facilitate size reduction. The next step is grinding. In the temperature range (between $20^{\circ} \mathrm{C}$ and $35^{\circ} \mathrm{C}$ ), it occurs the multiplication of mesophilic bacteria, which are mostly pathogenic to humans. 
5) After leaving the dryer and cooling, the solid will be brought to a mill for grinding. This aims to obtain the powdered product, thus reducing the size of the particles. Milling is a unitary size reduction operation in which the average solids size is reduced by the application of impact, compression and abrasion forces. The advantages of size reduction in processing are:

- Increased surface/volume ratio, thus increasing the efficiency of subsequent operations, such as extraction, heating, cooling, dewatering;

- Uniformity of the particle size of the product, aiding in the homogenisation of powdered products or solubilization of them (e.g. dehydrated soups, cake preparations, chocolates). Milling is a unitary operation often used in the processing of grains, to reduce them to flour or powder.

Grinding or milling can be considered to be very inefficient from an energy point of view. Only a small part of the energy is actually employed for the rupture or fragmentation of the solid. Most is used for the deformation of this solid and the creation of new lines of sensitivity that can produce the successive rupture of the fragments. The rest of the energy dissipates as heat.

The mill used was that of knives and hammer which in turn produce a finer material than the roller mill. For milling of cereals for the extraction of soluble powder, the roller mill is the most indicated, also being used the mills of knives and hammers and the disc mills. Knife and hammer mills usually perform better than disc mills for this purpose. A high speed rotor rotates inside a cylindrical cap. A series of hammers are coupled to the pivot points on the outside of the rotor. The material is broken by the impact of the hammers and is pulverized when passing through a mat in the opening between the hammers and the cover.

Figure 4 shows the knife mill that was used in this research (MA 048 MARCONI, $700 \mathrm{~W}$ ).

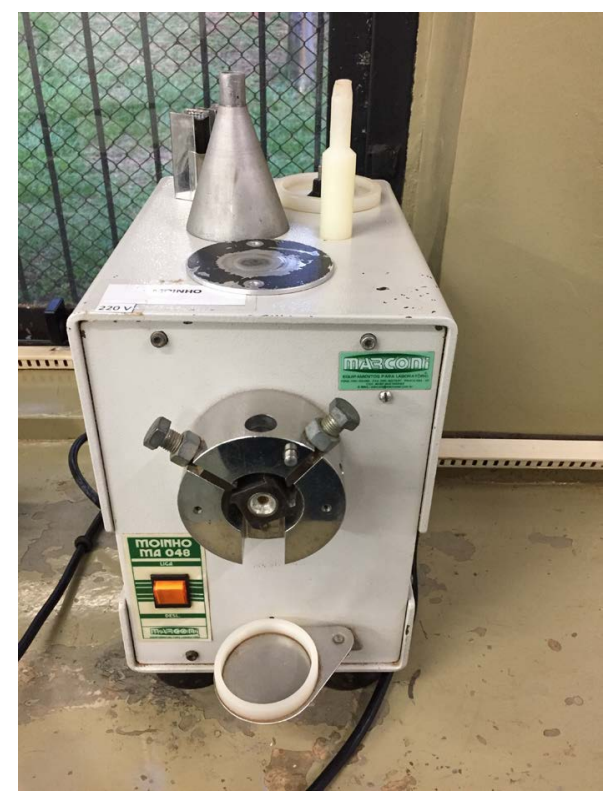

Figure 4. Mill MA-048 MARCONI. 
6) After the process the product underwent several analyzes for particle characterization, being:

i) Screening

Screening is a method of separating particles according to size. The undersize fines pass through the sieve apertures and the oversize retainer are retained on the sieve surface. A single sieve can separate a particulate feed into two fractions.

Material that is processed in a series of screens of different apertures (meshes) is separated into fractions of different sizes (see Figure 5).

The granulometric analysis is carried out with standard screens as to the opening of the meshes and the thickness of the threads from which they are made.

ii) Diameter of Sauter

Particle diameter whose surface/volume ratio is the same for all particles: Average Sauter Diameter: see the Equation (2).

$$
D_{S}=\frac{1}{\sum \frac{x_{i}}{d_{i}}}
$$

Being: ( $x_{i}$ is a mass fraction retained between two sieves and $d_{i}$ a medium between the openings of these sieves)

iii) Moisture

Determination of moisture is one of the most important measures used in food analysis. The moisture of a food is related to its stability, quality and composition, and can affect some characteristics of the product as:

- Storage: food stored at high moisture will deteriorate more quickly than those with low moisture. For example, grains with excessive moisture are subject to rapid deterioration due to the growth of fungi that develop toxins such as aflatoxin (carcinogenic).

- Packaging: some types of deterioration may occur in certain packaging if the food is too damp. For example, the speed of browning in dehydrated vegetables and fruits or the absorption of oxygen (oxidation) in egg powder may increase with increasing moisture, in light and oxygen permeable packages.

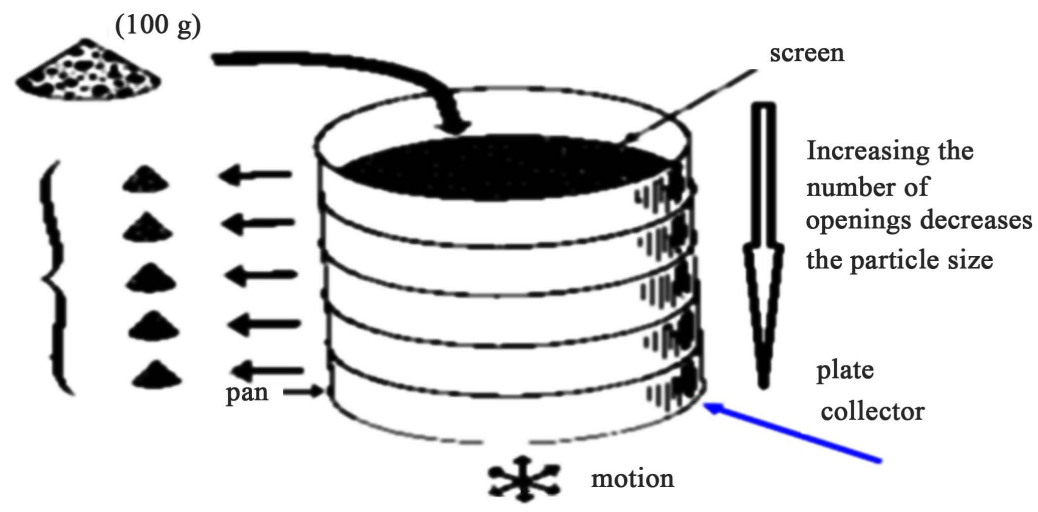

Figure 5. Granulometric analysis device. 
- Processing: the amount of water is important in the processing of various products.

Already in the method to determine the moisture of grains are classified in direct and indirect. In the direct method, water is withdrawn from the product by heating process, so the moisture content is calculated by the weight difference of the samples at the beginning and at the end of the process. This difference corresponds to the amount of water withdrawn.

\section{Results and Discussions}

Experiment 1: Drying of pequi at $40^{\circ} \mathrm{C}$ to find average moisture.

Some information:

- The experiment was done in triplicate and in each Petri dish was quantified 1 gram of pequi in each with the Petri dishes was enumerated as plate 1, plate 2 , plate 3 .

- Weight of each plate with pequi particles: Plate 1: 45.844 g; Plate 2: 45.956 g; Plate 3: $42.149 \mathrm{~g}$.

- The plates were left in the Fanem Orion 520 oven for 7 hours (see Figure 3).

- After 7 hours in the greenhouse we can verify that the moisture of the pequi did not occur more variations with this we verified that of each 1 g placed in the beginning remained the following final mass of the product in each plate respectively: $0.431 \mathrm{~g} ; 0.453 \mathrm{~g} ; 0.455 \mathrm{~g}$. Therefore it was observed that through the arithmetic mean the value of moisture was $55.37 \%$ (wet basis).

Experiment 2: Drying of pequi at $50^{\circ} \mathrm{C}$ to find average moisture.

Some information:

- Three Petri dishes were used, which were listed as plate 1, plate 2, plate 3.

- Amount of pequi 1 grams on all plates.

- The contact surface on plate 3 is larger than on plates 1 and 2 .

- Weight of each plate with pequi particles: Plate 1: 45.959 g; Plate 2: 45.838 g; Plate 3: $39.948 \mathrm{~g}$.

- After 12 hours in the greenhouse we can verify that the moisture of the pequi did not occur more variations with this we verified that of each $1 \mathrm{~g}$ placed in the beginning remained the following final mass of the product in each plate respectively: 0.402 grams; 0.407 grams; 0.394 grams. Therefore, it was observed that with the largest temperature of air and drying time had a greater loss of moisture and the arithmetic mean the value of moisture was $40.45 \%$.

Experiment 3: Drying of pequi at $60^{\circ} \mathrm{C}$ to find average moisture.

Some information:

- Three Petri dishes were used, which were listed as plate 1, plate 2, plate 3.

- Quantity of pequi 5grams on all plates (1,2 and 3).

- Weight of each plate without pequi particles: Plate 1: 40.45 g; Plate 2: 44.86 g; Plate 3: $38.97 \mathrm{~g}$.

Table 1 shows the time (hours) relation with the weight of the plaque with pequi. 
Table 1. Time (hours) relation with the weight of the plaque with pequi.

\begin{tabular}{cccc}
\hline Time (hours) & Plate 1 (g) & Plate 2 (g) & Plate 3 (g) \\
\hline 0 & 45.45 & 49.85 & 43.97 \\
1 & 44.25 & 48.55 & 42.77 \\
2 & 43.19 & 47.56 & 41.79 \\
3 & 42.90 & 47.29 & 41.42 \\
4 & 42.73 & 47.15 & 41.18 \\
5 & 42.68 & 47.12 & 41.18 \\
6 & 42.67 & 47.10 & 41.18 \\
7 & 42.66 & 47.09 & 41.18 \\
8 & 42.66 & 47.05 & 41.18 \\
9 & 42.66 & 47.05 & 41.18 \\
\hline
\end{tabular}

- We verified that after 8 hours in the greenhouse all 3 plates stabilized that no more variations occurred with this we confirmed that in the end of a total of 5 grams the following final mass of the product in each plate respectively: 2.21 grams; 2.19 grams; 2.21 grams; Therefore, through the arithmetic mean, the value of moisture was $55.94 \%$.

Experiment 4: Drying of pequi at $90^{\circ} \mathrm{C}$ to find average moisture. Some information:

- Three Petri dishes were used, which were listed as plate 1, plate 2, plate 3.

- Quantity of pequi 15 grams on plate 1 and plate 2.

- Quantity of pequi 9 grams on the plate 3.

- The contact surface on plates 1 and 2 are larger than plate 3. Weight of each plane without pequi particles: Plate 1: 106.5 g; Plate 2: 103.15 g; Plate 3: 41 g. Table 2 shows the time (hours) relation with the weight of the plaque with pequi.

- After 4 hours in the greenhouse we can verify that the moisture of the pequi did not occur more variations with this we verified that of each 15 grass placed in the beginning remained the following final mass of the product in each plate respectively: $7.87 \mathrm{~g} ; 7.75 \mathrm{~g}$ and on plate 3 that was quantified ggram of pequi remained $4.62 \mathrm{~g}$. Therefore, it was observed that the contact surface did not interfere because both had approximately $52.0 \%$ of moisture loss.

Experiment 5: Drying of pequi at $105^{\circ} \mathrm{C}$ to find average moisture.

Some information:

- Two Petri dishes were used that were enumerated as plate 1 and plate 2 .

- Quantity of pequi 50 grams on plate 1 and plate 2 .

- Weight of each plate without pequi particles: Plate 1: 104.06 g; Plate 2: 103.16 g.

Table 3 shows the relation with time (hours) and weight of the plaque with pequi. 
Table 2. Time (hours) relation with the weight of the plaque with pequi.

\begin{tabular}{cccc}
\hline Time (hours) & Plate $1(\mathrm{~g})$ & Plate 2 $(\mathrm{g})$ & Plate 3 $(\mathrm{g})$ \\
\hline 0 & 121.5 & 118.2 & 50.02 \\
1 & 113.7 & 110.6 & 46.15 \\
2 & 113.7 & 110.4 & 45.40 \\
3 & 113.7 & 110.4 & 45.39 \\
4 & 113.6 & 110.4 & 45.38 \\
5 & 113.6 & 110.4 & 45.38 \\
\hline
\end{tabular}

Table 3. Time (hours) relation with the weight of the plaque with pequi.

\begin{tabular}{ccc}
\hline Time (hours) & Plate 1 (g) & Plate 2 (g) \\
\hline 0 & 154.06 & 153.16 \\
1 & 125.69 & 125.30 \\
2 & 124.70 & 124.29 \\
3 & 124.66 & 124.20 \\
4 & 124.64 & 124.12 \\
5 & 124.62 & 124.12 \\
6 & 124.62 & 124.12
\end{tabular}

Thus, the mean mass remaining was $20.76 \mathrm{~g}$ of pequi and $41.52 \%$ of the initial mass and the initial moisture of pequi $58.4 \%$.

It was also observed, qualitatively, that with the high temperature used did not occur the loss of color and odor and that is characteristic of pequi in natura. The milling step was performed using a knife mill (see Figure 6). Soon after the milling stage, the granulometric analysis stage was carried out using the Tyler series of sieves. To establish a powder cor pattern a scale of surface coatings was used and RAL 1032 (Trojan Powder Coating-New York) closely approached the color of pequi powder.

\section{Granulometric analysis results}

The dried pequi particles dried at $105^{\circ} \mathrm{C}$ were separated with the Tyler series sieves and the mean particle size was obtained using the mean Sauter diameter. Table 4 shows the particle size analysis of drying at $105^{\circ} \mathrm{C}$.

It was calculated the diameter of sauter using Equation (2). This value (Ds = $0.606 \mathrm{~mm}$ ) represents the diameter of pequi powder particles. It was verified that in experiments 1,2, 3 and 4 that the higher the temperature the smaller the drying time for obtaining the dried pequi.

Laboratory analysis of the color, aroma and flavor of the product were not performed, and only qualitative analyzes were performed without quantitative measures which demonstrated a characteristic taste, aroma and color of pequi.

High temperatures, long exposure to heat treatments, irradiations and high oxygen concentration, lead to lipid oxidation and affect its physicochemical 


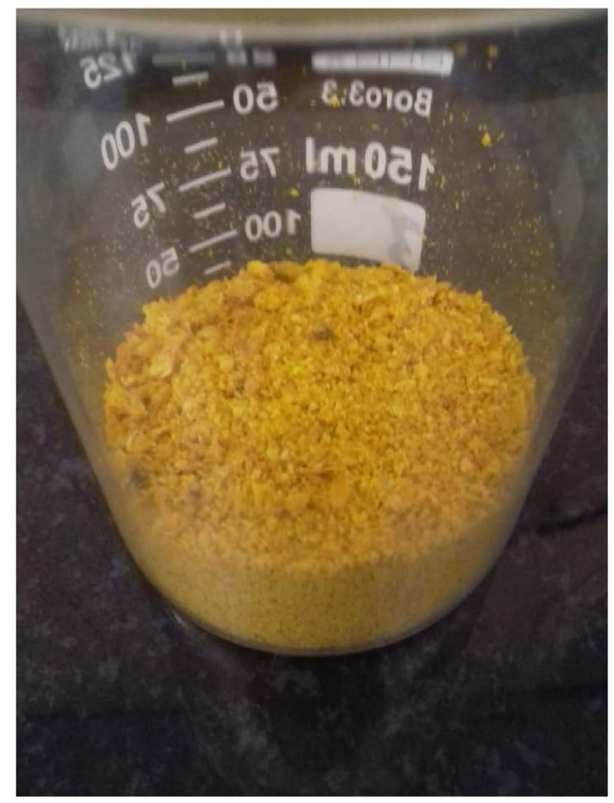

Figure 6. Sample of pequi after the milling process.

Table 4. Particle size analysis of drying at $105^{\circ} \mathrm{C}$.

\begin{tabular}{cccccccc}
\hline & $\begin{array}{c}\text { Diameter } \\
(\mathrm{mm})\end{array}$ & $\begin{array}{c}\text { Mean } \\
\text { diameter } \\
(\mathrm{mm})\end{array}$ & $\begin{array}{c}\text { Sieve weight } \\
\text { without } \\
\text { particles }(\mathrm{g})\end{array}$ & $\begin{array}{c}\text { Sieve } \\
\text { weight with } \\
\text { particles }(\mathrm{g})\end{array}$ & $\begin{array}{c}\text { Mass } \\
\text { retained }(\mathrm{g})\end{array}$ & $X_{i}$ & $\begin{array}{c}X_{i} / d_{i} \\
\left(\mathrm{~mm}^{-1}\right)\end{array}$ \\
\hline Seive 1 & 2.36 & 2.18 & 525.49 & 525.56 & 0.07 & 0.00335 & 0.001536 \\
Seive 2 & 2.0 & 1.5 & 456.36 & 456.44 & 0.08 & 0.00383 & 0.002553 \\
Seive 3 & 1.0 & 0.925 & 420.41 & 423.17 & 2.76 & 0.13231 & 0.143037 \\
Seive 4 & 0.85 & 0.725 & 384.64 & 394.31 & 9.67 & 0.46356 & 0.63939 \\
Seive 5 & 0.6 & 0.5125 & 380.56 & 387.08 & 6.52 & 0.31255 & 0.60985 \\
Seive 6 & 0.425 & 0.361 & 417.82 & 419.22 & 1.40 & 0.06711 & 0.18590 \\
Seive 7 & 0.297 & 0.2735 & 357.24 & 357.53 & 0.29 & 0.0139 & 0.05082 \\
Seive 8 & 0.250 & 0.231 & 409.75 & 409.79 & 0.04 & 0.00191 & 0.008268 \\
Seive 9 & 0.212 & 0.106 & 376.54 & 376.56 & 0.02 & 0.00095 & 0.008962 \\
Seive 10 & 0.0 & 0.0 & 384.64 & 384.65 & 0.01 & 0.00047 & 0.0 \\
& & & & & $\Sigma=20.86$ & $\Sigma=0.999$ & $\Sigma=1.6503$
\end{tabular}

properties [11]. Further studies should be performed to analyze effects on pequi powder.

\section{Conclusions}

The pequi powder can be a profitable activity, because the fruit is easy to grow, with fast and abundant return in its plantations, besides being a delicious food alternative of fast preparation for the Brazilian cuisine, being prepared in the most diverse shapes and flavors. 
In addition, it was noticed that a preliminary sensory evaluation of pequi powder showed that characteristics of color, aroma and flavor were maintained, same when processed at the temperature of $105^{\circ} \mathrm{C}$. In this case, probably the occurrence of a cooking action allowed an intensification of the characteristics of color, aroma and flavor.

Using the Trojan Powder Coating scale, it is found that pequi powder, dried at $105^{\circ} \mathrm{C}$, differs little in terms of the color of the fruit in nature.

\section{Conflicts of Interest}

The authors declare no conflicts of interest regarding the publication of this paper.

\section{References}

[1] Alho, C.J.R. and Martins, E.S. (1995) De grão em grão, o Cerrado perde espaço: Cerrado-Impactos do processo de ocupação. Fundo Mundial para a Natureza, Brasilia, 66 p.

[2] Chévez-Pozo, O.V.O. (1997) Pequi (Caryocar Brasiliense): Uma alternativa para o desenvolvimento sustentável do cerrado no norte de Minas Gerais. Dissertação de Mestrado. Universidade Federal de Lavras, MG, 100 p.

[3] Almeida, S.P. (1998) Cerrado: Aproveitamento Alimentar. Embrapa-CPAC, Planaltina, $188 \mathrm{p}$.

[4] Santana, A.A., Kurozawa, L.E., Oliveira, R.A. and Park, K.J. (2013) Influence of Process Conditions on the Physicochemical Properties of Pequi Powder Produced by Spray Drying. Drying Technology, 31, 825-836. https://doi.org/10.1080/07373937.2013.766619

[5] Morais, S.M., et al. (2009) Ação antioxidante de chás e condimentos de grande consumo no Brasil. Revista Brasileira de Farmacognosia Brazilian Journal of Pharmacognosy, 19, 315-320. https://doi.org/10.1590/S0102-695X2009000200023

[6] Suslow, T. (1999) Postharvest Chlorination: Basic Properties and Key Points for Effective Disinfection. In: Annual Workshop Fresh-Cut Products: Maintaining Quality and Safety, Vol. 5, University of California, California, 8.

[7] Antoniolli, L.R., et al. (2005) Efeito do hipoclorito de sódio sobre a microbiota de abacaxi "Pérola" minimamente processado. Revista Brasileira de Fruticultura, 27, 157-160. https://doi.org/10.1590/S0100-29452005000100041

[8] Maccabe, W.L., Smith, J.C. and Harriot, P. (2001) Unit Operations of Chemical Engineering. 6th Edition, McGraw Hill, Boston, 1114 p.

[9] Blackadder, D.A. and Nedderman, R.M. (2004) Manual de operações unitárias: Destilação de sistemas binários, extração de solvente, absorção de gases, sistemas de múltiplos componentes, trocadores de calor, secagem, evaporadores, filtragem. Hemus, São Paulo.

[10] Sfredo, M.A. (2006) Estudo da dispersão na secagem de frutos de café em secador de bandejas vibradas.

[11] Ramesh, M., et al. (1995) Microwave Treatment of Groundnut (Arachis hypogaea): Extractability and Quality of Oil and Its Relation to Lipase and Lipoxygenase Activity. Lebensmittel Wissenschaft und Technologie, 28, 96-99.

https://doi.org/10.1016/S0023-6438(95)80018-2 